\title{
Cinnamate-4-Hydroxylase Gene Is Involved in the Step of Lignin Biosynthesis in Chinese White Pear
}

\author{
Shutian Tao ${ }^{1}$, Danyang Wang, Cong Jin, Wei Sun, Xing Liu, and Shaoling Zhang ${ }^{1}$ \\ Pear Engineering Research Centre, College of Horticulture, Nanjing Agricultural University, \\ 1 Weigang, Nanjing, Jiangsu Province 210095, China
}

Fuyong Gao

Fengxian Agriculture and Forestry Bureau of Jiangsu Province, Fengxian, Jiangsu Province 221700, China

\author{
Shahrokh Khanizadeh \\ Eastern Cereal and Oilseed Research Centre, Agriculture and Agri-Food Canada, Ottawa, Ontario, \\ Canada K1A 0C6
}

\begin{abstract}
ADDITIONAL INDEX wORDs. Pyrus bretschneideri, $C 4 H$, lignification, stone cells, gene cloning, quantitative real-time RT-PCR
Abstract. Lignin is the main component of stone cells, and stone cell content is one of the crucial factors for fruit quality in chinese white pear (Pyrus $\times$ bretschneideri). The lignin biosynthesis pathway is complex and involves many enzymatic reactions. Cinnamate-4-hydroxylase [C4H (EC.1.14.13.11)] is an essential enzyme in lignin metabolism. This study was conducted to investigate the effect of bagging on lignin metabolism during fruit development in chinese white pear. The study showed that bagging had little effect on stone cell content, lignin content, $\mathrm{C} 4 \mathrm{H}$ activity, and $\mathrm{C4H}$ gene expression and that there was a positive correlation between $C 4 H$ gene expression and lignin content as well as stone cell content. Moreover, a full-length complementary DNA (cDNA) encoding $\mathrm{C4H}$ ( $\mathrm{PbrC4H}$, GenBank accession number KJ577541.1) was isolated from chinese white pear fruit. The cDNA is $1515 \mathrm{bp}$ long and encodes a protein of 504 amino acids. Sequence alignment suggested that the deduced protein belongs to the $P 450$ gene family and that $\mathrm{C} 4 \mathrm{H}$ might be located subcellularly in the cell membrane. The results indicate that bagging cannot change the lignin and stone cell content significantly and that $\mathrm{C} 4 \mathrm{H}$ catalyzes a step in lignin biosynthesis. These findings provide certain theoretical references and practical criteria for improving the quality of chinese white pear.
\end{abstract}

Pear (Pyrus sp.) is one of the most important fruit trees in temperate regions around the world. More than $60 \%$ of the world's pears are produced in China (Huang et al., 2009). Chinese white pear 'Dangshansuli' originated in China and is the most important commercial Asiatic pear cultivar grown in the world. Stone cells are rare in other fruit but are important features of fruit quality in pear. Pear flavor and quality can be affected by stone cell content and size, characteristics for which genetic variability appears to be the key factor. It has been reported that lignin is the principal component of stone cells in pear (Cai et al., 2010; Choi et al., 2007; Tao et al., 2009; Wu et al., 2013a). Damage to fruit caused by insect pests, birds, diseases, and mechanical injury can be prevented by bagging, a method that can not only improve the quality of fruit but also affect the formation of stone cells. However, there is of yet no clear consensus on whether bagging could affect stone cell formation in pear. Some research has shown that bagging can inhibit stone cell differentiation and development and reduce the size and density of stone cells, but certain researchers found that bagging could not reduce the amount of stone cells in 'Cuiguan' pear (Pyrus pyrifolia) or hinder stone cell development

Received for publication 27 Mar. 2015. Accepted for publication 14 Aug. 2015. We acknowledge the support that they received from the National Natural Science Foundation of China (31000888 and 31372044), the National HighTechnology Research and Development Program (2011AA10020602), and the Postdoctoral Science Foundation of Jiangsu Province (1002018B).

${ }^{1}$ Corresponding author. E-mail: taost@njau.edu.cn or nnzs1@njau.edu.cn.
(Hudina et al., 2012; Leite et al., 2014; Lin et al., 2009; Zhang et al., 2006).

Lignin plays an important role in the formation of stone cells. Likewise, as a primary component of plant cell walls, lignin performs important functions in terms of mechanical support, water transport, and stress responses (Ranadive and Haard, 1973; Tao et al., 2009; Xu et al., 2009). Lignin, the second most extensive natural polymer apart from cellulose, derives from the dehydrogenative polymerization of $p$-coumaroylajugol, coniferyl alcohol, 5-hydroxyconiferyl alcohol, and sinapyl alcohol (Zeng et al., 2010, 2014). Many of the enzymes involved in lignin biosynthesis are known. In certain cases, some appropriate genetic operations have been implemented to change the composition of lignin or reduce lignin content (Baucher et al., 1998; Chen and Dixon, 2007; Fu et al., 2011; Li et al., 2008; Weng and Chapple, 2010). So far, it is widely believed that $\mathrm{C} 4 \mathrm{H}$ catalyzes the conversion of trans-cinnamic acid to hydroxycinnamic acid, which is derived from phenylalanine by the action of phenylalanine ammonia lyase and located in the second step of the phenylpropanoid pathway (Hahlbrock and Scheel, 1989). As C4H plays a role in numerous metabolic pathways, including those of lignin and flavonoids, that enzyme has been studied extensively. As a common hydroxylase cytochrome P450-dependent monooxygenase in higher plants, $\mathrm{C} 4 \mathrm{H}$ is a member of the CYP73 family (Chapple, 1998). Both $\mathrm{C} 4 \mathrm{H}$ activity and $\mathrm{C} 4 \mathrm{H}$ gene expression are regulated by a variety of factors, and the activity of $\mathrm{C} 4 \mathrm{H}$ is positively correlated with lignin metabolism (Tabata, 1996). However, the formation of lignin was not found to be affected 
by the inhibition of $\mathrm{C} 4 \mathrm{H}$ activity via gene regulation in loblolly pine [Pinus taeda (Anterola et al., 2002)], and a reduction in $\mathrm{C} 4 \mathrm{H}$ activity was found to lead to a reduction in phenylpropanoid content in arabidopsis [Arabidopsis thaliana (Schilmiller et al., 2009)]. C4H genes have been identified in several plants, including Arabidopsis (Mizutani et al., 1997), rice [Oryza sativa (Yang et al., 2005)], pea [Pisum sativum (Frank et al., 1996)], aspen [Populus tremuloides (Lu et al., 2006)], and radix salviae miltiorrhizae [Salvia miltiorrhiza (Huang et al., 2008)]. To date, very little has been reported about the pear $\mathrm{C} 4 \mathrm{H}$ gene in the public database.

On the whole, bagging can affect the formation of stone cells, and lignin is the primary component of stone cells, thus, whether the bags could affect the lignin content in stone cells via the enzymes involved in lignin metabolism? Such as $\mathrm{C} 4 \mathrm{H}$, any influence of the bags on its activity and gene expression? In this study, bagging was employed as treatment to investigate the effect on lignin metabolism during pear fruit development. The results from this study may provide potential approaches to regulate pear quality development in cultural practice.

\section{Materials and Methods}

\section{Plant materials}

For this study, 15-year-old 'Dangshansuli' chinese white pear trees growing in a commercial orchard in Xuzhou, Jiangsu Province, China, were used. From the same farm, 40 strong and healthy trees were chosen and divided uniformly into two groups, one each for the bagging and the control treatments. The fruit of the first group were used as controls and exposed to the air, and the fruit of the second group were covered at $21 \mathrm{~d}$ after full bloom (DAFB) by using double-layer paper bags with a brown outer layer and a black inner layer, also with two gas-exchange holes at the bottom. Samples of the fruit were picked at $21,34,46,58,70,98$, and 161 DAFB. In sampling, two fruit from each tree were collected, and all the samples from each group were required to be relatively consistent in size. All fruit were taken to the laboratory with ice box for future testing. In the laboratory, samples were peeled and cored, then cut into small pieces and mixed together. Some pieces of fruit were then immediately frozen in liquid nitrogen and stored at $-80{ }^{\circ} \mathrm{C}$ until isolation of total RNA and extraction of enzymes. And the rest samples were temporarily stored at $4{ }^{\circ} \mathrm{C}$ for fresh tests as described below.

\section{Methods}

Measurement of stone Cell content. A 100 -g mixed sample of pear flesh was taken to measure stone cell content by using the method of Tao et al. (2009) and Cai et al. (2010). Sample was stored at $-20^{\circ} \mathrm{C}$ for $24 \mathrm{~h}$, and then homogenized at
$18,000 \mathrm{rpm}$ for $5 \mathrm{~min}$ with distilled water. The suspension was stirred with a glass rod for $3 \mathrm{~min}$ and then precipitated at room temperature for $30 \mathrm{~min}$. The supernatant was discarded, and the precipitate was suspended in $0.5 \mathrm{~mol} \cdot \mathrm{L}^{-1} \mathrm{HCl}$ for $30 \mathrm{~min}$ and then washed with distilled water. This process was repeated several times until the stone cells were separated from impurities. Finally, the gathered stone cells were oven dried at $65^{\circ} \mathrm{C}$ and weighed. The procedure was repeated three times.

Lignin Determination. The mixed sample $(8.0 \mathrm{~g})$ was collected and oven-dried at $65{ }^{\circ} \mathrm{C}$ for lignin determination by Klason method (Raiskila et al., 2007). Dried samples were ground with methanol into powder using a pestle and dried in a fume hood overnight. The powder samples $(200 \mathrm{mg})$ were treated with $15 \mathrm{~mL}$ of $72 \% \mathrm{H}_{2} \mathrm{SO}_{4}$ at $30{ }^{\circ} \mathrm{C}$ for $1 \mathrm{~h}$. The mixture was diluted with $100 \mathrm{~mL}$ of distilled water and then boiled for $1 \mathrm{~h}$. The volume of the mixture was kept constant during this procedure. The admixture was filtered with $500 \mathrm{~mL}$ of boiled distilled water to remove impurities and the residue was dried at $65^{\circ} \mathrm{C}$ and then weighed. The assay was repeated three times.

C4H ENZYME EXTRACTION AND ACTIVITY ASSAY. About $20 \mathrm{~g}$ mixed samples from each treatment that had been stored at $-80^{\circ} \mathrm{C}$ were used for this assay. For $\mathrm{C} 4 \mathrm{H}$ analysis, $\mathrm{C} 4 \mathrm{H}$ activity was extracted using a modified version of the method of Lamb and Rubery (1975). Frozen pulp (6g) was ground to a fine powder in liquid nitrogen using a mortar and pestle. A 5-g sample of the powder was extracted using a $10 \mathrm{~mL}$ solution of $0.05 \mathrm{~mol} \cdot \mathrm{L}^{-1}$ Tris$\mathrm{HCl}$ buffer ( $\mathrm{pH} 8.9$ ) containing $15 \mathrm{mmol} \cdot \mathrm{L}^{-1} \beta$-mercaptoethanol, $4 \mathrm{mmol} \cdot \mathrm{L}^{-1} \mathrm{MgCl}_{2}, 2.5 \mathrm{mmol} \cdot \mathrm{L}^{-1}$ ascorbic acid, $10 \mu \mathrm{mol} \cdot \mathrm{L}^{-1}$ leupeptin, $1 \mathrm{mmol} \cdot \mathrm{L}^{-1}$ phenylmethylsulfonyl fluoride, $0.15 \%$ polyvinylpyrrolidone, and $10 \%$ glycerin. The homogenate was centrifuged at $12,000 g_{\mathrm{n}}$ for $20 \mathrm{~min}$ at $4{ }^{\circ} \mathrm{C}$. The supernatant was collected and then stored at $4{ }^{\circ} \mathrm{C}$ for the measurement of $\mathrm{C} 4 \mathrm{H}$ activity. The reaction mixtures contained $2.2 \mathrm{~mL}$ of $0.05 \mathrm{~mol} \cdot \mathrm{L}^{-1}$ Tris- $\mathrm{HCl}$ buffer (pH 8.9; consisting of $2 \mu \mathrm{mol} \cdot \mathrm{L}^{-1}$ trans-cinnamic acid, $2 \mu \mathrm{mol} \cdot \mathrm{L}^{-1} \beta$-nicotinamide adenine dinucleotide phosphate disodium salt, and $5 \mu \mathrm{mol} \cdot \mathrm{L}^{-1}$ D-glucose 6-phosphate sodium salt hydrate). Then, $0.3 \mathrm{~mL}$ of the extract was added into the mixture to initiate the reaction. The mixture was agitated at $25^{\circ} \mathrm{C}$ for $30 \mathrm{~min}$, and the reaction was stopped by adding $100 \mu \mathrm{L}$ of $6 \mathrm{~mol} \cdot \mathrm{L}^{-1} \mathrm{HCl}$. The activity of $\mathrm{C} 4 \mathrm{H}$ was assayed by measuring the increase in absorbance at $340 \mathrm{~nm}$. One unit of $\mathrm{C} 4 \mathrm{H}$ activity was defined as the amount of enzyme catalyzing an increase in absorbance of 0.01 per minute per gram fresh weight. The step was repeated three times.

RNA EXTRACTION AND CDNA sYNTHESIS. For $C 4 H$ expression analysis and $C 4 H \mathrm{cDNA}$ clone isolation, total RNA was isolated from the fruit samples collected and treated as described above, according to the protocol of Gasic et al. (2004). The integrity of RNA was detected with agarose gel electrophoresis, and the total RNA was quantified using a spectrophotometer (NanoDrop;

Table 1. Sequence of primers to investigate the cinnamate-4-hydroxylase $(C 4 H)$ gene expression pattern with quantitative real-time polymerase chain reaction (qRT-PCR).

\begin{tabular}{llcr}
\hline Code & \multicolumn{1}{c}{ Primer sequences $\left(5^{\prime}-3^{\prime}\right)$} & Amplicon length (bp) & Application \\
\hline C4H-1 & Sense: CAGTTCACTCTCCCACACAA & 1,622 & Complementary DNA cloning \\
& Antisense: GAATCAAAATCTTCCTCCCC & & Complete open reading frame \\
C4H-2 & Sense: CATGCCATGGATGGACCTCCTCCT & 1,515 & amplification of C4H gene \\
& Antisense: GGACTAGTCGCTATCGGCTTCATCAC & 75 & qRT-PCR \\
C4H-3 & Sense: GACACCTCGGAGAAAGGTGG & & \\
& Antisense: CGCTATCGGCTTCATCACAA & & \\
\end{tabular}


Thermo Scientific, Wilmington, DE) by measuring absorbance at both 260 and $280 \mathrm{~nm}$.

Genomic DNA was removed by DNaseI (Invitrogen, Shanghai, China) digestion as per the manufacturer's instructions, and cDNAs were generated using the ReverTra Ace qPCR RT Kit (Toyobo, Osaka, Japan) following the manufacturer's recommendations to a final volume of $20 \mu \mathrm{L}$.

Quantitative ReAL-TIME RT-PCR. The primers used in the present study to investigate the $\mathrm{C} 4 \mathrm{H}$ expression pattern in fruit tissues with different treatments are listed (Table 1). The gene quantification was performed using SYBR Green Master Mix (TaKaRa, Otsu, Japan) according to the manufacturer's instructions. Each $20-\mu \mathrm{L}$ reaction was run in triplicate, and the above mixture consisted of $5.5 \mu \mathrm{L}$ of nuclease-free water, $12.5 \mu \mathrm{L}$ of $10 \times$ buffer, $0.5 \mathrm{~m}$ of each primer, and $1 \mu \mathrm{L}$ of diluted cDNA. The polymerase chain reaction (PCR) amplifications were performed as follows: $5 \mathrm{~min}$ of incubation at $95^{\circ} \mathrm{C}$, followed by 45 cycles of $10 \mathrm{~s}$ at $94^{\circ} \mathrm{C}, 30 \mathrm{~s}$ at $60^{\circ} \mathrm{C}$, and $30 \mathrm{~s}$ at $72{ }^{\circ} \mathrm{C}$, and a final extension of $3 \mathrm{~min}$ at $72^{\circ} \mathrm{C}$. One internal gene, PyrusEF $\alpha 1$ (EF $\alpha 1$, GenBank accession number AY338250), was used to evaluate the quantitative reverse transcription PCR (qRT-PCR) assays (Wu et al., 2013b). After each extension step, fluorescence data were collected. The melting curves were checked for singles, and no-template controls for each primer were included in each run in all circumstances. The relative messenger RNA level was calculated by a formula using the relative $2^{-\triangle \Delta C T}$ method (Livak and Schmittgen, 2001). Each qRT-PCR analysis was performed in triplicate.

Gene Cloning and Sequencing of PCR products. The corresponding nucleotide sequences of $\mathrm{C} 4 \mathrm{H}$ in the National Center for Biotechnology Information (NCBI) database from plants in the Rosaceae family were obtained. For the amplification of $\mathrm{C} 4 \mathrm{H}$, a group of primers was designed from those conserved regions. The forward and reverse primers applied for this study are provided in Table 1. Using the cDNA synthesized above as the template, the PCR reaction mixture contained $5 \mu \mathrm{L}$ of $10 \times$ LA PCR Buffer (TaKaRa), $5 \mu \mathrm{L}$ of $2 \mathrm{~mm} \mathrm{MgCl}_{2}, 8 \mu \mathrm{L}$ of $2.5 \mathrm{~mm}$ deoxyribonucleotide triphosphate Mix, $1 \mu \mathrm{L}$ of $20 \mu \mathrm{M}$ of each primer, $0.5 \mu \mathrm{L}$ of $5 \mathrm{U} \cdot \mu \mathrm{L}^{-1}$ LA Taq DNA polymerase (TaKaRa), $3 \mu \mathrm{L}$ of synthesized cDNA, and sterilized distilled water, to a total volume of $50 \mu \mathrm{L}$. Cycling conditions were $3 \mathrm{~min}$ at $94^{\circ} \mathrm{C}$, followed by 40 cycles of $30 \mathrm{~s}$ at $94{ }^{\circ} \mathrm{C}, 30 \mathrm{~s}$ at $58{ }^{\circ} \mathrm{C}$, and $1 \mathrm{~min}$ $30 \mathrm{~s}$ at $72{ }^{\circ} \mathrm{C}$, and a final extension of $10 \mathrm{~min}$ at $72{ }^{\circ} \mathrm{C}$. A no-template control reaction was also performed.

The amplified products were analyzed on $1.2 \%$ agarose gel, and a specific PCR product was resected from 1.2\% agarose gel. After its purification using the QIAEX II Gel Extraction Kit from Qiagen (Valencia, CA), the purified product was transformed into pMD19-T vector (TaKaRa) according to the manufacturer's instructions and then cloned into Escherichia coli $\mathrm{DH} 5 \alpha$ competent cells. Recombinants were screened with the same primer pairs as those applied to the original amplification by PCR. The selected recombinants with appropriate inserts of the expected size were sequenced commercially at Invitrogen.

Bioinformatics ANALysis. Sequence alignments and homology sequence searches in databases were carried out using the NCBI Basic Local Alignment Search Tool (BLAST) web page (Beck et al., 2013). Deduced amino acid sequences were obtained with the Primer 5.0 software program (Premier Biosoft, Palo Alto, CA). Phylogenetic relationships among sequences were determined with the MEGA 6.06 software program (MEGA, Tempe, AZ). The molecular structure and physicochemical properties of proteins were analyzed with the ProtParam tool (Gasteiger et al., 2005). The secondary structures of deduced protein sequences were aligned with the PredictProtein tool (Rost et al., 2004). The subcellular location of eukaryotic proteins was predicted using the Softberry program (Iskandar et al., 2014).

Subcellular localization of $\boldsymbol{P}_{\boldsymbol{B} \boldsymbol{R}} \boldsymbol{C} 4 \boldsymbol{H}$. The accurately sequenced recombinants described above were selected and then plasmids were purified with the Plasmid Mini Kit (Qiagen).The entire $C 4 H$ open reading frame (ORF) was amplified by PCR employing the primers for $\mathrm{C} 4 \mathrm{H}-2$ (NcoI restriction site and SpeI restriction site underlined) indicated in Table 1 and using the plasmids described above as the template. The resulting 1500-bp PCR products digested with NcoI and SpeI were purified after agarose gel electrophoresis and
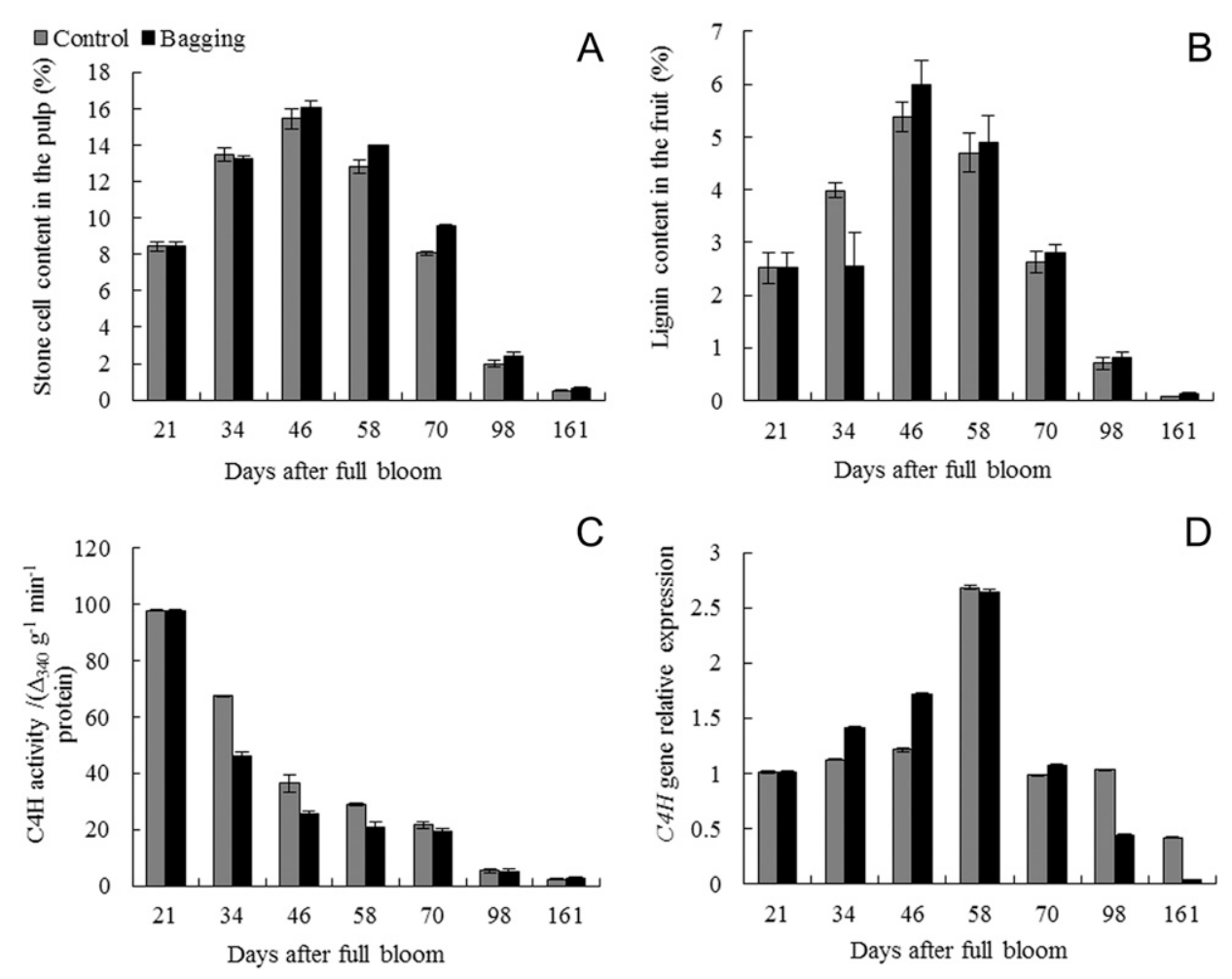

Fig. 1. Effects of fruit bagging on chinese white pear fruit development: (A) changes of stone cell content, (B) changes of lignin content, $(\mathbf{C})$ cinnamate-4-hydroxylase $(\mathrm{C} 4 \mathrm{H})$ activity, and $(\mathbf{D}) \mathrm{C} 4 \mathrm{H}$ gene expression pattern by using quantitative real-time polymerase chain reaction. All data are reported as the average of three repeated determinations. Vertical bars represent the SE. 
transferred into pMD19-T vector, according to the manufacturer's instructions (TaKaRa). The amplified fragment was sequenced commercially at Invitrogen. In this way, the ORF of the $C 4 H$ gene included restriction sites $N c o$ I at the $5^{\prime}$ region of the forward primer and SpeI at the $3^{\prime}$ region of the reverse primer, which allowed subcloning into $p C A M B I A 1302$ vector containing the green fluorescent protein (GFP) reporter gene to generate a $p C A M B I A 1302-P b r C 4 H$-GFP fusion under the control of the CaMV $35 \mathrm{~S}$ promoter. The $p C A M B I A 1302$ vector was used as the control. Subsequently, the control vector and the recombinant plasmid were transferred into agrobacterium strain GV3101 (Agrobacterium tumefaciens), which was used for transformation of onion (Allium cepa) epidermal cells in accordance with Huang et al. (2011). These onion epidermal cells had been grown in advance on Murashige and Skoog (MS) medium in darkness at $28{ }^{\circ} \mathrm{C}$ for $24 \mathrm{~h}$. After transformation, these cells were cultured on the same MS medium in darkness at $28{ }^{\circ} \mathrm{C}$ for $48 \mathrm{~h}$. The transient expression of the $\mathrm{C} 4 \mathrm{H}$-GFP fusion protein was visualized using a universal fluorescence microscope (IX75; Olympus, Tokyo, Japan).

\section{Statistical analysis}

All data were generated from triplicate experiments and reported as the average of three replicates. Analysis of variance was calculated by using the SPSS statistical software package (IBM, Armonk, NY).

\section{Results}

EFFECTS OF BAGGING ON STONE CELL AND LIGNIN CONTENT IN THE FRUIT. Bagging had no significant effect on stone cell content in the pulp (Fig. 1A). The stone cell content and lignin content in the pulp of the bagged and nonbagged pears showed a similar tendency. Both contents followed a rise-fall pattern during the period of fruit development. The stone cell content in the pulp of the bagged fruit reached a maximum of $16.05 \%$ at 46 DAFB and then declined, and the stone cell content in the control fruit peaked at $15.45 \%$ at the same time and decreased thereafter. The highest lignin content appeared at 46 DAFB, reaching 5.98\% in the bagged fruit and 5.37\% in the controls (Fig. 1B). On the basis of the data analysis from Fig. 1A and B, stone cell content in the pulp was positively correlated with the lignin content in the pulp under the bagging treatment $(r=$ $0.925299)$. Likewise, a positive correlation $(r=0.961835)$ was discovered between the stone cell content and the lignin content in the fruit of the nonbagged pears. Correlation analysis indicated that a significant correlation existed between the stone cell content in the pulp of the bagged and nonbagged fruit $(r=0.994256)$ and that a positive correlation existed between the lignin content in the fruit of the bagged and nonbagged fruit $(r=0.921684)$.

Changes in C4H aCtivities in the fRuit under bagging. For the diversification of $\mathrm{C} 4 \mathrm{H}$ activities, a similar tendency emerged for the bagged and nonbagged fruit, with a downward trend beginning at 21 DAFB (Fig. 1C). The activities of $\mathrm{C} 4 \mathrm{H}$ were lower in the bagged fruit than in the control fruit at all fruit developmental stages. The activities of $\mathrm{C} 4 \mathrm{H}$ were high in the initial period of fruit development and then declined rapidly at 34 DAFB in both the bagged and the control fruit. The trend in $\mathrm{C} 4 \mathrm{H}$ activities remained stable from 46 to 70 DAFB. At maturity, however, $\mathrm{C} 4 \mathrm{H}$ activities reached a low level in the fruit under both bagging and the control treatment.
KJ577541.1 A.AY 87450.1 $\mathrm{ABX} 74779.1$ AEA02458.1 Consensus

KJ577541.1 AAY87450.1 ABX74779.1 AEA02458.1 Consensus

KJ577541.1 AAY87450.1 ABX74779.1

AEA02458. 1 Consensus

KJ577541.1 A.AY87450.1 ABX74779.1 AEA02 458.1 Consensus

KJ577541.1 AAY87450.1 ABX74779.1 AEA02458.1 Consensus

KJ577541.1 AAY87450.1 ABX74779.1 AEA02458.1 Consensus

KJ577541.1 AAY87450.1 ABX74779.1 AEA02458. 1 Consensus

KJ577541.1 AAY87450.1 ABX74779.1 AEA02458. 1 Consensus

KJ577541.1 AAY 87450.1 ABX74779.1 AEA02458.1 Consensus

KJ577541.1 AAY87450.1 ABX74779.1

AEA02458.1 Consensus

KJ577541.1 AAY 87450.1 ABX74779.1 AEA02 458.1 Consensus

KJ577541.1 AAY87450.1 ABX74779.1 AEA02458.1 Consensus

KJ577541.1 AAY 87450.1 ABX74779.1 AEA02458.1 Consensus

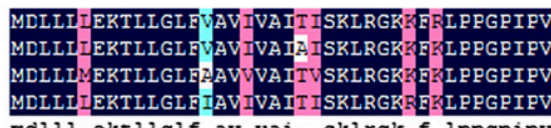

mdlll ektllglf av vai sklrgk f lppgpipv

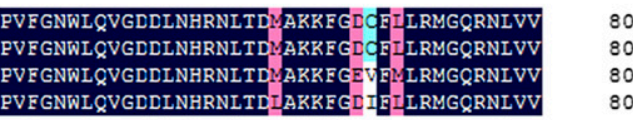

pvfgnwlqvgddlnhrnltd akkfg f lrmggrnlvv
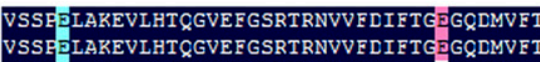
SSEDLAKEVLHTCGVEFGSRTRNVVEDIFT GKGQDMVF SSEDLAREVLHTQQGVEFSRTRNVVFDIFTEEGQDMVFT

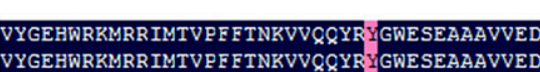

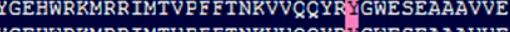
VYGEHWRKMRRIMTVPF FTNKVVQQYRY YWESEAAAVVED
VYGEHWRKMRRIMTVPFFTNKVVQQYRHGWESEAAAVVED vygehwrkmrrimtvpfftnkvqquyr gweseaavved

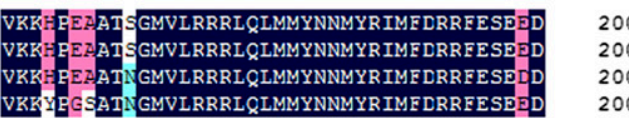

200

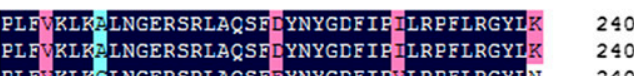

240

240

240

plf $\mathrm{klk}$ lngersrlagsf ynygdfip lrpflrgyl

280
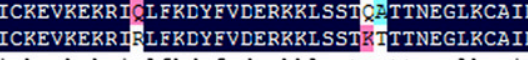

ickevkekri lfkdyfvderkklsst ttneglkcaid
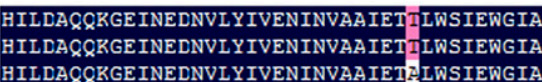
ILDACORGE INEDNVIY YVENINVAA IETILNSIEWGI

hildagqkgeinednvlyiveninvaaiet lwsiewgia

320

320

320

320
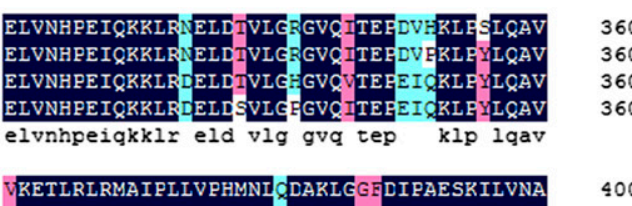

400
400

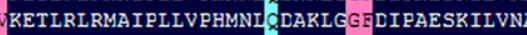
KETLRLRMAIPLLVPHMNLFDAKLGG EDIPAESKILVNA KETLRLRMA I PLLVPHMNLNDAKLGSYDIPAESKILVNA

ketlrlrmaipllvphmnl daklg dipaeskilvna

400

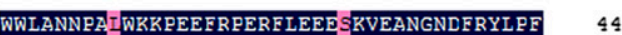

440

440

440

440

WLANNPA IWKKPEEFRPERFLEEDZRVEANGNDFRYLP

wwlannpa wkkpeefrperfleee kveangndfrylpf

480

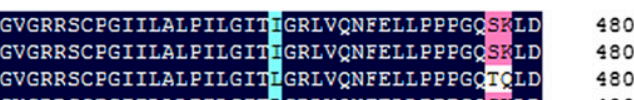

GVRRSCPGI ILAL PIIGITIGRLVQNFELLPPPG C TCDD 480

GVRRSCPGI ILALPILGITIGRLVQNFELLPPPGQ STL

480

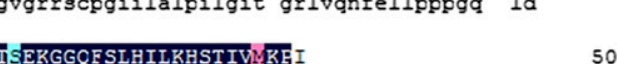

503

503

503

Fig. 2. Alignment of the predicted amino acid sequences of cinnamate-4hydroxylase $(\mathrm{C} 4 \mathrm{H})$ genes with $\mathrm{C} 4 \mathrm{H}$ proteins from chinese white pear and other plants. Accession numbers for species are as follows: KJ577541.1 (chinese white pear), AAY87450.1 (apple), ABX74779.1 (raspberry), AEA02458.1 (apricot). The common conserved domains in the cytochrome P450 monooxygenase family are marked in blue. 
DIFFERENTIAL EXPRESSION ANALYSIS OF C4H GENES DURING FRUIT DEVELOPMENT. The expression patterns of the ligninbiosynthesis-related $\mathrm{C} 4 \mathrm{H}$ gene in the bagged and nonbagged fruit during different developmental stages are shown in Fig. 1D. Little difference in $\mathrm{C} 4 \mathrm{H}$ relative expression between the bagged and control fruit was seen $(r=0.902802)$. In both treatments, the expression peaked at 58 DAFB and declined rapidly at $70 \mathrm{DAFB}$, and there was a positive correlation $(r=$ 0.772035 ) between lignin content (Fig. 1B) and $\mathrm{C} 4 \mathrm{H}$ expression in the fruit (Fig. 1D). The expression levels of the $\mathrm{C} 4 \mathrm{H}$ gene showed a rise-fall tendency during fruit growth and did not match with their respective activities. However, both $\mathrm{C} 4 \mathrm{H}$ relative expression and $\mathrm{C} 4 \mathrm{H}$ activities reached their lowest points at harvest. The expression level of the $\mathrm{C} 4 \mathrm{H}$ gene was slightly higher in the bagged fruit than in the controls in early fruit development, but then $\mathrm{C} 4 \mathrm{H}$ expression in the fruit approaching maturity remained at a comparatively high level in the controls (Fig. 1D).

ISOLATION AND ANALYSIS OF CDNA CLONE ENCODING C4H. A full-length cDNA of $C 4 H$ was cloned from the fruit by RT-PCR, sequenced, and submitted to the NCBI database (accession number KJ577541.1). The $C 4 H \mathrm{ORF}$ is 1515 -bp long and encodes a polypeptide of 504 amino acid residues with a predicted molecular mass of $57.69 \mathrm{kDa}$ and a predicted isoelectric point of 9.06. Self-Optimized Prediction Method with Alignment (SOPMA) analysis suggested that the deduced $\mathrm{C} 4 \mathrm{H}$ contained $\alpha$-helices $(49.01 \%)$, random coils $(35.32 \%)$, extended strands $(10.71 \%)$, and $\beta$-turns (4.96\%) in its secondary structure. Simple Modular Architecture Research Tool (SMART) analysis showed that $\mathrm{C} 4 \mathrm{H}$ is a member of the cytochrome $\mathrm{P} 450$ monooxygenase family. In a BLAST search, $\mathrm{C} 4 \mathrm{H}$ revealed a high level of identity to apple [Malus $\times$ domestica $(99.01 \%)$, raspberry [Rubus coreanus (93.05\%)], and apricot [Prunus armeniaca (93.25\%)] (Fig. 2). Phylogenetic analysis suggested that there was an intimate relationship between $\mathrm{C} 4 \mathrm{H}$ from 'Dangshansuli' pear and $\mathrm{C} 4 \mathrm{H}$ from other plants belonging to the Rosaceae family, especially apple [AAY87450.1 (Fig. 3)].

Subcellular localization of C4H. To monitor the subcellular localization of the $\mathrm{PbrC} 4 \mathrm{H}$ protein, the $\mathrm{PbrC} 4 \mathrm{H}$-GFP fusion protein was constructed by subcloning the $\mathrm{PbrC} 4 \mathrm{H}$ coding region without the stop codon into the upstream of the

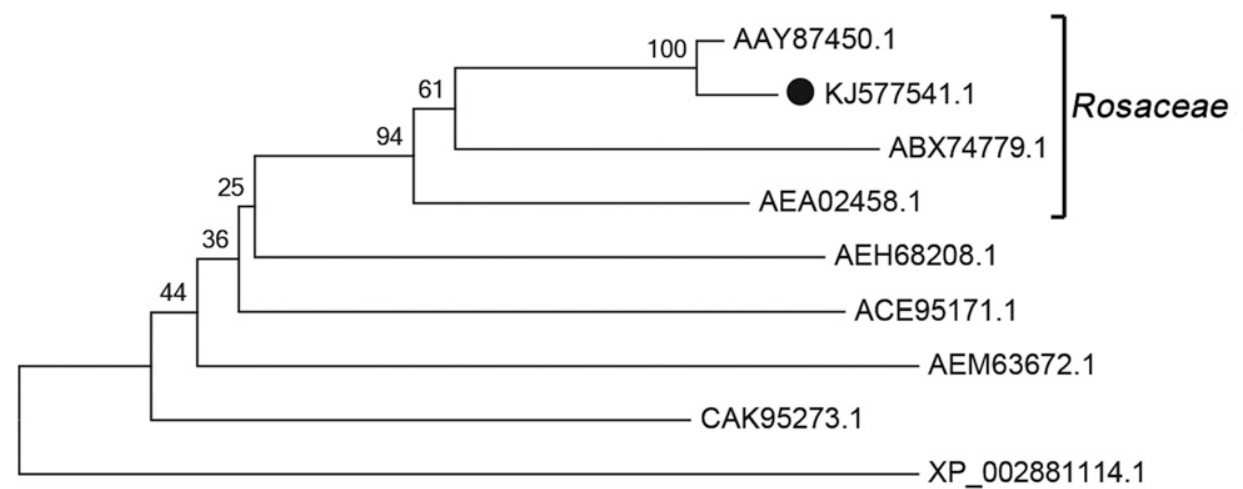

0.02

Fig. 3. Phylogenetic analysis of cinnamate-4-hydroxylase genes from chinese white pear and other plants. The phylogenetic tree was created using the MEGA 6.06 software program. Accession numbers for species are as follows: KJ577541.1 (chinese white pear), AAY87450.1 (apple), ABX74779.1 (raspberry), AEA02458.1 (apricot), AEH68208.1 (Astragalus mongholicus), ACE95171.1 (Populus tomentosa), CAK95273.1 (Cucumis sativus), AEM63672.1 (Platycodon grandiflorus), XP002881114.1 (Arabidopsis lyrata).
GFP protein gene in pCAMBIA1302, and the fusion gene was expressed under the control of the CaMV $35 \mathrm{~S}$ promoter. Fluorescence microscopy of the onion epidermis cells transformed with the $C 4 H$-GFP fusion construct showed that GFP fluorescence was targeted into the membrane with the $\mathrm{C} 4 \mathrm{H}$ GFP fusion plasmid. In contrast, fluorescence was found in the entire cytoplasm and nucleus transformed with the GFP control plasmid. These results suggest that $\mathrm{C} 4 \mathrm{H}$ might be located subcellularly in the cell membrane (Fig. 4).

\section{Discussion}

The accumulation of stone cells in pear fruit has attracted the attention of many researchers. It was reported that lignin plays a key role in the formation of stone cells. Lignin is deposited on the cell walls of pear fruit and makes the secondary cell wall thicker (Cai et al., 2010, Choi et al., 2007, Jin et al., 2013, Lu et al., 2011, Tao et al., 2009). The increase in stone cell content leads to tissue lignification, which can influence fruit texture and postharvest handling (Cai et al., 2006). The present study found a strong correlation between the formation of stone cells and lignin biosynthesis, a finding that supports the view that lignin plays an important role in the synthesis of stone cells. However, there were some differences in the conclusions reached concerning whether bagging can reduce the stone cell content, as a result of differences in terms of cultivation environment and fruit bag materials (Zhang et al., 2006).

Lignin is regulated by enzymes together with their corresponding genes, which participate in the formation, transportation, and polymerization of lignin (Anterola and Lewis, 2002). C4H, a key enzyme of lignin monomer synthesis, is in the middle step of the lignin synthesis metabolism process, can this enzyme be influenced by bagging, and thus affect the content of stone cells and lignin? Some studies showed that inhibition of $\mathrm{C} 4 \mathrm{H}$ activity could not reduce the lignin content in loblolly pine (Anterola et al., 2002). The present study found that bagging subdued the activity of $\mathrm{C} 4 \mathrm{H}$ and that there was no close relationship between $\mathrm{C} 4 \mathrm{H}$ activity and lignin content. Interestingly, the $\mathrm{C} 4 \mathrm{H}$ gene expression pattern showed a change tendency similar to that of lignin, and bagging had little effect on gene expression during fruit development. In this study, a gene encoding $\mathrm{C} 4 \mathrm{H}$ was isolated from chinese white pear. The gene has the common conserved domains in the cytochrome P450 monooxygenase family and shares the highest identity with $\mathrm{C} 4 \mathrm{H}$ from other Rosaceae plants.

As the full length of pear $\mathrm{C} 4 \mathrm{H}$ has been obtained, the subcellular localization of the $\mathrm{C} 4 \mathrm{H}$ gene was conducted for further study. This technology was opened up by Chalfie et al. (1994), the fusion gene expression of GFP and exogenous genes, expressed in living cells over the long term, does not affect the function and conformation of exogenous proteins and produce toxin in cells, in which the migration and position of proteins can be detected using a fluorescence microscope or flow cytometer (Wang and Hazelrigg, 


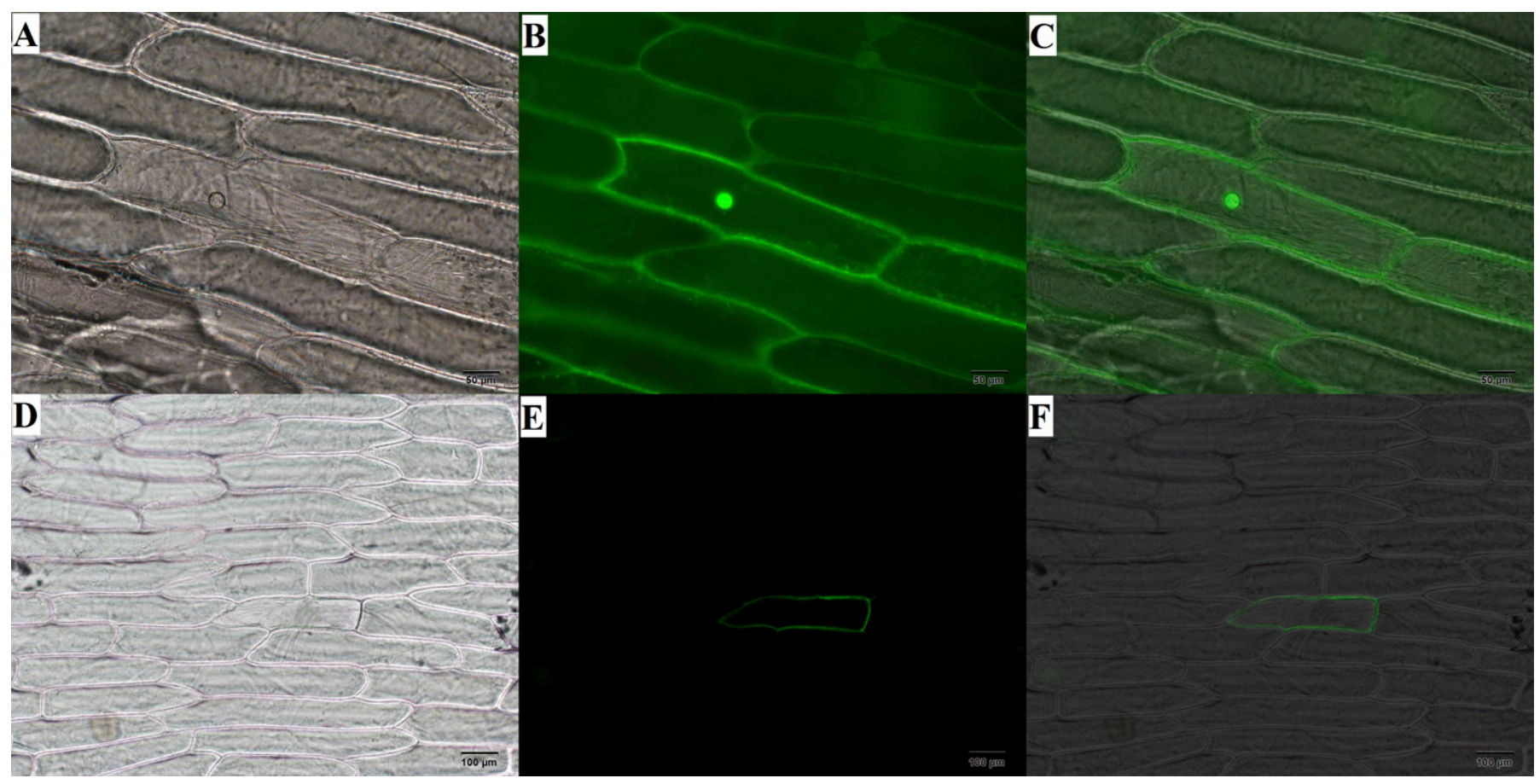

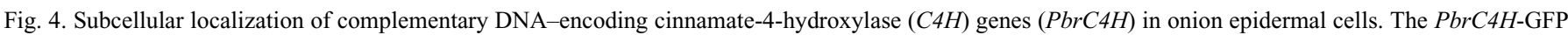
fusion construct $(\mathbf{A}, \mathbf{B}$, and $\mathbf{C})$ and the green fluorescent protein (GFP) control (D, $\mathbf{E}$, and $\mathbf{F}$ ) plasmid were separately transformed into onion epidermal cells by agrobacterium-mediated infection. The transformed cells were observed by fluorescence microscopy. Photographs $\mathbf{A}$ and $\mathbf{D}$ were taken in bright field mode, and photographs $\mathbf{B}$ and $\mathbf{E}$ were taken in dark field mode. $\mathbf{C}$ and $\mathbf{F}$ are the overlapped photographs of the representative cells expressing GFP and the $\mathrm{Pbr} C 4 \mathrm{H}$-GFP fusion protein, respectively.

1994). Cytochrome P450s are considered to be anchored in the endoplasmic reticulum generally, as is the case with the subcellular localization of aspen $\mathrm{C} 4 \mathrm{H}$ (Ro et al., 2001). However, some cytochrome P450s are localized in the provacuole (Madyastha et al., 1977). Nevertheless, the subcellular localization of $C 4 H$ was found to be different in different plants (Benveniste et al., 1978; Smith et al., 1994). In this study, the membrane localization of the pear $\mathrm{C} 4 \mathrm{H}$ gene was confirmed by transformation into onion epidermal cells, a confirmation that provides some evidence for exploring gene function.

From the results of this study, bagging can affect the content of stone cell and lignin, but not significantly. However, on the basis of the final content of stone cells and lignin in the mature fruit and the activity of $\mathrm{C} 4 \mathrm{H}$ and $\mathrm{C} 4 \mathrm{H}$ expression pattern during the fruit whole development, we can conclude that the $\mathrm{C} 4 \mathrm{H}$ is indeed involved in the step of lignin biosynthesis. Unfortunately, bagging is not a good choice to increase pear fruit quality by reducing stone cell content, maybe the quality but not the strength of light can influence the formation of stone cells in pear fruit? This requires further more studies, and we are doing some experiments now in culture practice.

\section{Literature Cited}

Anterola, A.M., J.H. Jeon, L.B. Davin, and N.G. Lewis. 2002. Transcriptional control of monolignol biosynthesis in Pinus taeda: Factors affecting monolignol ratios and carbon allocation in phenylpropanoid metabolism. J. Biol. Chem. 277:18272-18280.

Anterola, A.M. and N.G. Lewis. 2002. Trends in lignin modification: A comprehensive analysis of the effects of genetic manipulations/ mutations on lignification and vascular integrity. Phytochemistry 61:221-294.
Baucher, M., B. Monties, M.V. Montagu, and W. Boerjan. 1998. Biosynthesis and genetic engineering of lignin. Crit. Rev. Plant Sci. 17:125-197.

Beck, J., D. Benson, J. Coleman, M. Hoeppner, M. Johnson, D. Maglott, I. Mizrachi, R. Morris, J. Ostell, K. Pruitt, W. Rubinstein, E. Sayers, K. Sirotkin, and T. Tatusova. 2013. The NCBI Handbook. 2nd ed. 2 Sept. 2014. <http://www.ncbi.nlm.nih.gov/books/NBK143764/>.

Benveniste, I., J.P. Salaün, and F. Durst. 1978. Phytochrome-mediated regulation of a monooxygenase hydroxylating cinnamic acid in etiolated pea seedlings. Phytochemistry 17:359-363.

Cai, C., C.J. Xu, X. Li, I. Ferguson, and K.S. Chen. 2006. Accumulation of lignin in relation to change in activities of lignification enzymes in loquat fruit flesh after harvest. Postharvest Biol. Technol. 40:163-169.

Cai, Y.P., G.Q. Li, J.Q. Nie, Y. Lin, F. Nie, J.Y. Zhang, and Y.L. Xu. 2010. Study of the structure and biosynthetic pathway of lignin in stone cells of pear. Sci. Hort. 125:374-379.

Chalfie, M., Y. Tu, G. Euskirchen, W.W. Ward, and D.C. Prasher. 1994. Green fluorescent protein as a marker for gene expression. Science 263:802-805.

Chapple, C. 1998. Molecular-genetic analysis of plant cytochrome P450-dependent monooxygenases. Annu. Rev. Plant Physiol. Plant Mol. Biol. 49:311-343.

Chen, F. and R.A. Dixon. 2007. Lignin modification improves fermentable sugar yields for biofuel production. Nature Biotechnol. 25:759-761.

Choi, J.H., J.J. Choi, K.H. Hong, W.S. Kim, and S.H. Lee. 2007. Cultivar differences of stone cells in pear flesh and their effects on fruit quality. Hort. Environ. Biotechnol. 48:27-31.

Frank, M.R., J.M. Deyneka, and M.A. Schuler. 1996. Cloning of wound-induced cytochrome P450 monooxygenases expressed in pea. Plant Physiol. 110:1035-1046.

Fu, C.X., J.R. Mielenz, X.R. Xiao, Y.X. Ge, C.Y. Hamilton, Jr., M. Rodriguez, F. Chen, M. Foston, A. Ragauskas, J. Bouton, R.A. 
Dixon, and Z.Y. Wang. 2011. Genetic manipulation of lignin reduces recalcitrance and improves ethanol production from switchgrass. Proc. Natl. Acad. Sci. USA 108:3803-3808.

Gasic, K., A. Hernandez, and S.S. Korban. 2004. RNA extraction from different apple tissues rich in polyphenols and polysaccharides for cDNA library construction. Plant Mol. Biol. Rpt. 22:437-438.

Gasteiger, E., C. Hoogland, A. Gattiker, S. Duvaud, M.R. Wilkins, R.D. Appel, and A. Bairoch. 2005. Protein Identification and Analysis Tools on the ExPASy Server. 5 Oct. 2014. <http://web.expasy. org/docs/expasy_tools05.pdf>.

Hahlbrock, K. and D. Scheel. 1989. Physiology and molecular biology of phenylpropanoid metabolism. Annu. Rev. Plant Physiol. Plant Mol. Biol. 40:347-369.

Huang, B., Y. Duan, B. Yi, L. Sun, B. Lu, X. Yu, H. Sun, H. Zhang, and W. Chen. 2008. Characterization and expression profiling of cinnamate 4-hydroxylase gene from Salvia miltiorrhiza in rosmarinic acid biosynthesis pathway. Russ. J. Plant Physiol. 55:390-399.

Huang, C.H., B. Yu, Y.W. Teng, J. Su, Q. Shu, Z.Q. Cheng, and L.Q. Zeng. 2009. Effects of fruit bagging on coloring and related physiology, and qualities of red chinese sand pears during fruit maturation. Sci. Hort. 121:149-158.

Huang, X.S., T. Luo, X.Z. Fu, Q.J. Fan, and J.H. Liu. 2011. Cloning and molecular characterization of a mitogen-activated protein kinase gene from Poncirus trifoliata whose ectopic expression confers dehydration/drought tolerance in transgenic tobacco. J. Expt. Bot. 62:5191-5206.

Hudina, M., F. Stampar, P. Orazem, M.M. Petkovsek, and R. Veberic. 2012. Phenolic compounds profile, carbohydrates and external fruit quality of the 'Concorde' pear (Pyrus communis L.) after bagging. Can. J. Plant Sci. 92:67-75.

Iskandar, H.M., D. Widyaningrum, and S. Suhandono. 2014. Cloning and characterization of P5CS1 and P5CS2 genes from Saccharum officinarum L. under drought stress. J. Trop. Crop Sci. 1:23-30.

Jin, Q., C.C. Yan, J.Q. Qiu, N. Zhang, Y. Lin, and Y.P. Cai. 2013. Structural characterization and deposition of stone cell lignin in Dangshan Su pear. Sci. Hort. 155:123-130.

Lamb, C. and P. Rubery. 1975. A spectrophotometric assay for transcinnamic acid 4-hydroxylase activity. Anal. Biochem. 68:554-561.

Leite, G.L.D., A. Fialho, J.C. Zanuncio, R.R. Júnior, and C.A. Da Costa. 2014. Bagging tomato fruits: A viable and economical method of preventing diseases and insect damage in organic production. Fla. Entomol. 97:50-60.

Li, X., J.K. Weng, and C. Chapple. 2008. Improvement of biomass through lignin modification. Plant J. 54:569-581.

Lin, J., X.G. Li, Q.S. Yang, and Y.H. Chang. 2009. Effects of bagging mode on fruits quality, pesticides residues and storage of Cuiguan pear. Jiangsu J. Agr. Sci. 1:174-176.

Livak, K.J. and T.D. Schmittgen. 2001. Analysis of relative gene expression data using real-time quantitative PCR and the $2^{-\Delta \Delta C T}$ method. Methods 25:402-408.

Lu, S., Y.H. Zhou, L.G. Li, and V.L. Chiang. 2006. Distinct roles of cinnamate 4-hydroxylase genes in Populus. Plant Cell Physiol. 47:905-914.

Lu, X.P., Y.Z. Liu, J.C. An, H.J. Hu, and S.A. Peng. 2011. Isolation of a cinnamoyl CoA reductase gene involved in formation of stone cells in pear (Pyrus pyrifolia). Acta Physiol. Plant. 33:585-591.

Madyastha, K.M., J.E. Ridgway, J.G. Dwyer, and C.J. Coscia. 1977. Subcellular localization of a cytochrome P-450-dependent monooxygenase in vesicles of the higher plant Catharanthus roseus. J. Cell Biol. 72:302-313.

Mizutani, M., D. Ohta, and R. Sato. 1997. Isolation of a cDNA and a genomic clone encoding cinnamate 4-hydroxylase from Arabidopsis and its expression manner in plants. Plant Physiol. 113:755-763.

Raiskila, S., M. Pulkkinen, T. Laakso, K. Fagerstedt, M. Löija, R. Mahlberg, L. Paajanen, A.C. Ritschkoff, and P. Saranpää. 2007.
FTIR spectroscopic prediction of Klason and acid soluble lignin variation in norway spruce cutting clones. Silva Fennica 41:351-371. Ranadive, A.S. and N.F. Haard. 1973. Chemical nature of stone cells from pear fruit. J. Food Sci. 38:331-333.

Ro, D.K., N. Mah, B.E. Ellis, and C.J. Douglas. 2001. Functional characterization and subcellular localization of poplar (Populus trichocarpa $\times$ Populus deltoides) cinnamate 4-hydroxylase. Plant Physiol. 126:317-329.

Rost, B., G. Yachdav, and J. Liu. 2004. The PredictProtein Server. 12 Sept. 2014. <http://www.ncbi.nlm.nih.gov/pmc/articles/ PMC441515/pdf/gkh377.pdf $>$.

Schilmiller, A.L., J. Stout, J.K. Weng, J. Humphreys, M.O. Ruegger, and C. Chapple. 2009. Mutations in the cinnamate 4-hydroxylase gene impact metabolism, growth and development in Arabidopsis. Plant J. 60:771-782.

Smith, C.G., M.W. Rodgers, A. Zimmerlin, D. Ferdinando, and G.P. Bolwell. 1994. Tissue and subcellular immunolocalisation of enzymes of lignin synthesis in differentiating and wounded hypocotyl tissue of french bean (Phaseolus vulgaris L.). Planta 192:155-164.

Tabata, M. 1996. The mechanism of shikonin biosynthesis in Lithospermum cell cultures. Plant Tissue Cult. Lett. 13:117-126.

Tao, S.T., S. Khanizadeh, H. Zhang, and S.L. Zhang. 2009. Anatomy, ultrastructure and lignin distribution of stone cells in two Pyrus species. Plant Sci. 176:413-419.

Wang, S. and T. Hazelrigg. 1994. Implications for $b c d$ mRNA localization from spatial distribution of exu protein in Drosophila oogenesis. Nature 369:400-403.

Weng, J.K. and C. Chapple. 2010. The origin and evolution of lignin biosynthesis. New Phytol. 187:273-285.

Wu, J., G. Zhao, Y.N. Yang, W.Q. Le, M.A. Khan, S.L. Zhang, C. Gu, and W.J. Huang. 2013b. Identification of differentially expressed genes related to coloration in red/green mutant pear (Pyrus communis L.). Tree Genet. Genomes 9:75-83.

Wu, J., Z.W. Wang, Z.B. Shi, S. Zhang, R. Ming, S.L. Zhu, M.A. Khan, S.T. Tao, S.S. Korban, H. Wang, N.J. Chen, T. Nishio, X. Xu, L. Cong, K.J. Qi, X.S. Huang, Y.T. Wang, X. Zhao, J.Y. Wu, C. Deng, C.Y. Gou, W.L. Zhou, H. Yin, G.H. Qin, Y.H. Sha, Y. Tao, H. Chen, Y.N. Yang, Y. Song, D.L. Zhan, J. Wang, L.T. Li, M.S. Dai, C. Gu, Y.Z. Wang, D.H. Shi, X.W. Wang, H.P. Zhang, L. Zeng, D.M. Zheng, C.L. Wang, M.S. Chen, G.B. Wang, L. Xie, V. Sovero, S.F. Sha, W.J. Huang, S.J. Zhang, M.Y. Zhang, J.M. Sun, L.L. Xu, Y. Li, X. Liu, Q.S. Li, J.H. Shen, J.Y. Wang, R.E. Paull, J.L. Bennetzen, J. Wang, and S.L. Zhang. 2013a. The genome of the pear (Pyrus bretschneideri Rehd.). Genome Res. 23:396-408.

Xu, Z.Y., D.D. Zhang, J. Hu, X. Zhou, X. Ye, K.L. Reichel, N.R. Stewart, R.D. Syrenne, X.H. Yang, P. Gao, W.B. Shi, C. Doeppke, R.W. Sykes, J.N. Burris, J.J. Bozell, Z.M. Cheng, D.G. Hayes, N. Labbe, M. Davis, C.N. Stewart, and J.S. Yuan. 2009. Comparative genome analysis of lignin biosynthesis gene families across the plant kingdom. BMC Bioinformatics 10(Suppl. 11):S3 doi: 10.1186/1471-2105-10-S11-S3.

Yang, D.H., B.Y. Chung, J.S. Kim, J.H. Kim, P.Y. Yun, Y.K. Lee, Y.P. Lim, and M.C. Lee. 2005. cDNA cloning and sequence analysis of the rice cinnamate-4-hydroxylase gene, a cytochrome P450-dependent monooxygenase involved in the general phenylpropanoid pathway. J. Plant Biol. 48:311-318.

Zeng, Y.N., B.G. Saar, M.G. Friedrich, F. Chen, Y.S. Liu, R.A. Dixon, M.E. Himmel, X.S. Xie, and S.Y. Ding. 2010. Imaging lignindownregulated alfalfa using coherent anti-Stokes Raman scattering microscopy. BioEnergy Res. 3:272-277.

Zeng, Y.N., S. Zhao, S.H. Yang, and S.Y. Ding. 2014. Lignin plays a negative role in the biochemical process for producing lignocellulosic biofuels. Curr. Opin. Biotechnol. 27:38-45.

Zhang, Z.M., S.L. Zhang, Y.J. Qiao, S.T. Tao, Y.C. Miao, and H.L. Cao. 2006. Effect of bagging with different types of bags on fruit quality of Dangshansu pear cultivar. J. Fruit Sci. 4:510-514. 